\author{
Kazimierz Zaras* \\ Jean-Charles Marin ${ }^{* *}$ \\ Bryan Trudel $^{* * *}$
}

\title{
IDENTIFYING STRATEGIC DEVELOPMENT \\ OBJECTIVES FOR EUROPEAN UNION STATES USING THE DOMINANCE-BASED ROUGH SET APPROACH: THE CASE OF POLAND
}

DOI: $10.22367 / \mathrm{mcdm} .2019 .14 .09$

\begin{abstract}
The use of the dominance-based rough set approach (DRSA) to help identify and prioritize strategic political, economic, sociological and technological (PEST) objectives for European Union (EU) countries is presented. The countries are first grouped into three categories: [A] those that are doing well according to the selected indicators; [B] those that need support to acquire category A status; [C] those ranked the lowest and needing special support with regard to the criteria considered. The categories correspond to tertiles within the average ranking of all EU countries. DRSA then provides decision rules based on PEST needs in order to improve the development and classification of the country. We conclude that by using this methodology, the EU could identify the strategic objectives to be given priority in order to stimulate its economic development or to improve the economic and sociological status of any country in the union. The case of Poland, a category $\mathrm{C}$ country from an economic perspective, is of particular interest.
\end{abstract}

Keywords: international development, European Union, international aid, economic growth, strategic objectives, rough-set theory, dominance-based rough set approach, selection of portfolio projects, multicriteria analysis, sustainable development.

\footnotetext{
* Université du Québec en Abitibi-Témiscamingue, Rouyn-Noranda, Canada, e-mail: kazimierz.zaras@uqat.ca

** Université du Québec en Abitibi-Témiscamingue, Rouyn-Noranda, Canada, e-mail: marj103@uqat.ca

*** Université du Québec en Abitibi-Témiscamingue, Rouyn-Noranda, Canada, e-mail: bryan.trudel@uqat.ca
} 


\section{Introduction}

This study proposes a systematic approach to helping Poland and the European Union identify strategic objectives to improve their status as compared to similar economies, using a combination of statistics and dominance-based rough set approach (DRSA). The approach began with a selection of statistical data drawn from various references. The selected variables included in our database were grouped into four different perspectives, namely: political, economic, sociological and technological. The countries were then ranked from each perspective, to obtain a weighted average. The final step was the use of DRSA to identify decision rules and conditions applicable specifically to Poland. These conditions represent strategic objectives that could be pursued in order to improve the development of this country relative to others in the EU.

\subsection{Review of the literature}

Proposed initially by Pawlak $(1982,1991)$ and then by Pawlak and Slowinski (1994), the rough set theory is a mathematical tool devised to support decision-making processes. Since its introduction, it has been used in many fields such as medicine, banking, engineering, learning, location selection, pharmacology, finance, market analysis and economics (Pawlak, 2002; Greco et al., 1999, 2001; Zaras, 2004; Zaras et al., 2012; Ho et al., 2016; Renaud et al., 2007; Marin et al., 2014; Prema and Umamaheswari, 2016; Songbian, 2016; Emam et al., 2017). It was later extended by Greco, Matarazo and Slowinski $(2001,1999)$ and renamed "dominance-based rough set approach". Zaras then enlarged it to include mixed data, such as deterministic, probabilistic and fuzzy sets (2004). The purpose of the present study is to use DRSA to identify strategic policies that EU decision makers and leaders could implement in order to stimulate the development of the EU or of any of its member nations. For this purpose, 22 variables were selected, which were categorized as political, economic, sociological or technological. DRSA is expected to aid the decision maker to prioritize strategic objectives, based on actual data and results obtained for Poland.

\subsection{Interactive approach}

The proposed interactive approach (Figure 1) begins with the selection of indicators representing the four perspectives: political, economic, sociological and technological. The next step is to collect data from various databases. The multicriteria classification is then carried out to divide the countries into three categories for geographical analysis and production of the decision table. The 
DRSA method is then used to obtain the decision rules by induction, followed by the strategic objectives to be recommended by the central decision-maker (CDM), who implements the actions intended to improve a country's position in the ranking. Once actions are completed at the local decision-maker (LDM) level, an audit should be carried out to verify whether or not the ranking has indeed improved. For this purpose, the CDM returns to data collection and multi-criteria classification.

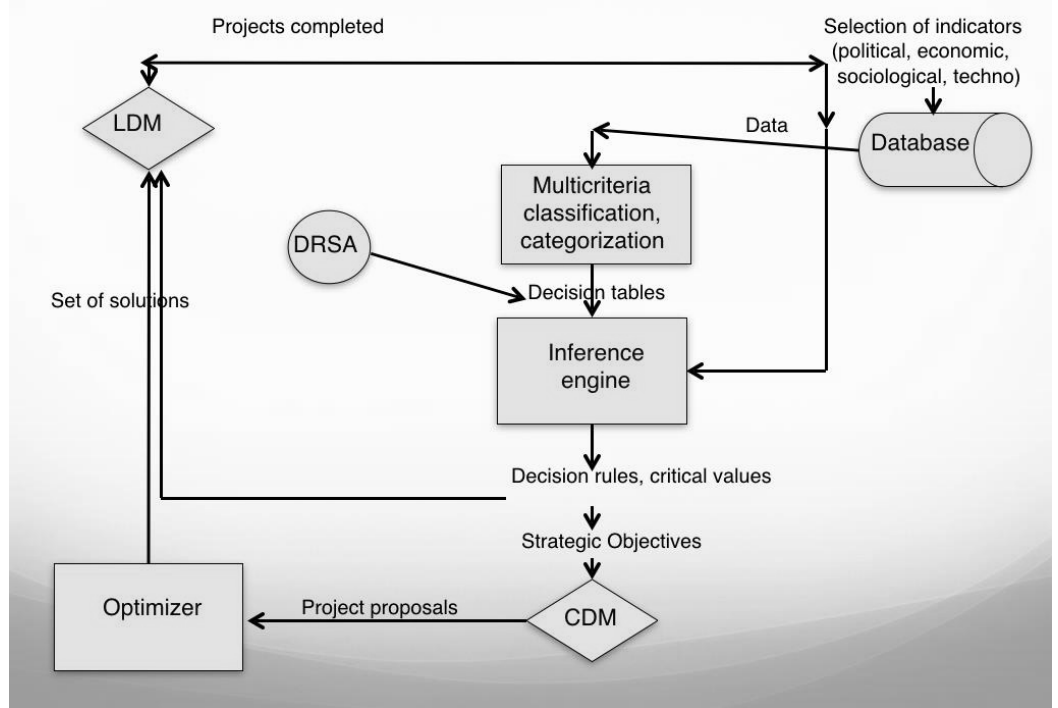

Figure 1: Interactive approach

\section{Multicriteria classification}

To obtain data for the 22 variables considered in this study, we searched the websites of the World Bank (2018), the United Nations (2018) and also the International Institute for Strategic Studies (2018) during the period from January 2018 to March 2018.

\subsection{Political, economic, sociological and technological indicators}

Data were categorized in one of the four perspectives, namely: political, economic, sociological and technological (PEST) as summarized in Table 1. 
Table 1: Summary of the PEST indicators considered in this study

\begin{tabular}{|c|c|c|c|c|}
\hline $\begin{array}{c}\text { Perspective } \\
\text { or measurement }\end{array}$ & Definition & Indicator & $\begin{array}{c}\uparrow=\text { higher } \\
\text { is better } \\
\downarrow=\text { lower is } \\
\text { better }\end{array}$ & Poland \\
\hline \multicolumn{5}{|l|}{ Political } \\
\hline 1.1 Global Peace Index & $\begin{array}{l}\text { Number of deaths resulting directly from internal conflict } \\
\text { involving at least one governmental armed force (2017) }\end{array}$ & Scale $1-5$ & $\downarrow$ & 1.676 \\
\hline 1.2 Military expenditure & $\begin{array}{l}\text { Cash outlays of central or federal government to meet the } \\
\text { costs of national armed forces (2017) }\end{array}$ & Scale $1-5$ & & 1.922 \\
\hline 1.3 Corruption perception index & $\begin{array}{l}\text { Based on ranking of countries according to the extent to } \\
\text { which corruption is believed to exist (2017) }\end{array}$ & Scale $0-100$ & $\uparrow$ & 62 \\
\hline 1.4 Global competitiveness index & Competitiveness along various axes (2017) & Scale 1-7 & $\uparrow$ & 4.59 \\
\hline 1.5 Ease of doing business index & Ease of completing business transactions (2017) & World rank & $\downarrow$ & 27 \\
\hline 1.6 Women in government & $\begin{array}{l}\text { Proportion of seats held by women in national parliaments } \\
\text { (2017) }\end{array}$ & $\%$ & $\uparrow$ & 28 \\
\hline \multicolumn{5}{|l|}{ Economic } \\
\hline $\begin{array}{l}2.1 \text { Adjusted net national income } \\
\text { per capita }\end{array}$ & $\begin{array}{l}\text { Adjusted net national income per capita (Current USD, } \\
\text { 2017) }\end{array}$ & $\$$ & $\uparrow$ & $10,617.14$ \\
\hline 2.2 GNP per capita & Gross national product per capita (USD Constant, 2016) & $\$$ & $\uparrow$ & $15,074.73$ \\
\hline 2.3 GNI per capita & $\begin{array}{l}\text { Gross national income per capita Atlas method (Current } \\
\text { USD, 2016) }\end{array}$ & $\$$ & $\uparrow$ & 12,690 \\
\hline 2.4 Unemployment & Unemployment, total (\% of labor force, 2017 ) & $\%$ & $\uparrow$ & 5.1 \\
\hline 2.5 Exports of G\&S & Exports of goods and services (\% of GNP, 2017) & $\%$ & $\uparrow$ & 52.26 \\
\hline \multicolumn{5}{|l|}{ Sociological } \\
\hline 3.1 Life expectancy, female & Life expectancy at birth, female (years, 2017) & Years & $\uparrow$ & 82.2 \\
\hline 3.2 Life expectancy, male & Life expectancy at birth, male (years, 2017). & Years & $\uparrow$ & 74.4 \\
\hline 3.3 School age & Average age when schooling is terminated (2017) & Years & $\uparrow$ & 16 \\
\hline 3.4 Urban population & Percentage of the population living in urban areas (2017) & $\%$ & & 60.53 \\
\hline 3.5 Adolescent fertility & Number of births per 1,000 women aged 15-19 (2017) & Number & $\downarrow$ & 13.03 \\
\hline 3.6 Intentional homicides & $\begin{array}{l}\text { Death inflicted deliberately on a person by another person } \\
(2017)\end{array}$ & Scale $1-5$ & $\downarrow$ & 1.35 \\
\hline \multicolumn{5}{|l|}{ Technological } \\
\hline 4.1Productivity of academia & $\begin{array}{l}\text { Number of scientific articles published per } 1000000 \\
\text { persons (2017) }\end{array}$ & Number & $\uparrow$ & 157.38 \\
\hline 4.2 Internet use & Percentage of active population using the Internet (2017) & $\%$ & $\uparrow$ & 73.3 \\
\hline 4.3 Fixed Internet & $\begin{array}{l}\text { Fixed broadband Internet subscriptions per } 100 \text { persons } \\
(2017)\end{array}$ & Number & $\uparrow$ & 19.22 \\
\hline 4.4 Secure Internet & Secure Internet servers per million persons (2017) & Number & $\uparrow$ & 763.73 \\
\hline 4.5 Mobile phones & Mobile cellular subscription per 100 persons (2017) & Number & $\uparrow$ & 146.21 \\
\hline
\end{tabular}


We thus selected six political, five economic, six sociological and five technological indicators. The political indicators are mostly complex, taking into account the opinions of international groups of experts, panels and think tanks. They are published every year; for example, the Global Peace Index is published by the Institute for Economics and Peace, military expenditure by the International Institute for Strategic Studies, the Corruption Perceptions Index by Transparency International, the Global Competitiveness Index by the World Economic Forum, the Index of ease of doing business by the World Bank, and so on. In Table 1, the values of the indicators are given for 2017, except for GNP and GNI, which are given for 2016. The status of Poland is indicated in the rightmost column.

\subsection{Formulation of the multicriteria problem}

Our first task was to obtain the overall ranking of the 28 countries based on the 22 indicators or criteria. This was then repeated for each perspective according to the respective criteria. This approach can be described using the AXE model, where:

$A$ is a finite set of countries $a_{i}, i=1,2 \ldots 28$;

$X$ is a finite set of criteria $X_{k}, k=1,2 \ldots 22$ or of criteria $X_{k j}$ for each perspective $j$,

$$
\text { where } k_{j}=1,2 \ldots n_{j} \text { and } \Sigma n_{j}=22
$$

$E$ is the set of evaluations measured by indicators $e_{i, k}$ with respect to criterion $X_{k}$ or indicators $e_{i, k j}$ with respect to criterion $X_{k j}$ for each perspective j.

The weighted average rank method was used to obtain the ranking of the countries. They were ranked from the most to the least preferable with respect to each indicator in relation to each criterion. Thereafter, since the weights of the indicators were considered equal at the outset, we calculated the weighted average rank for each country. This enabled us to obtain the ranking of the countries with respect to a given perspective as well as for the overall classification.

For each perspective $j$, the weighted average of country $i$,

$$
r_{i_{j}}=\sum_{k_{j}} w_{k_{j}} r_{k_{j} i}
$$

The overall weighted average of country $i$,

$$
r_{i}=\sum_{k} w_{k} r_{k i}
$$

where: $w_{k}$ is the weight of criterion $k$ and $w_{k_{j}}$ for perspective $j ; r_{k i}$ a rank of country $i$ with respect to criterion $k$ and $r_{k_{j}}$ for perspective $j$. 
Having obtained the rankings for the 28 countries, overall and for each perspective, the next step was to group them into categories $\mathrm{A}, \mathrm{B}$ and $\mathrm{C}$, as shown in Table 2.

From this table, we can deduce the following heuristic rules for our sorting task: category A countries earn an A score for at least two perspectives; category B countries receive at most one $\mathrm{C}$ score; category $\mathrm{C}$ countries receive a $\mathrm{C}$ score for at least two perspectives. Table 2 shows that Poland currently earns an overall B score. Decision makers may propose to take actions designed to improve its ranking relative to the rest of the European Union. By extracting decision rules, the DRSA explanatory method allows us to identify the criteria that are most relevant to achieving this as well as the critical values that need to be reached.

Table 2: Overall classification of the 28 UE countries, based on the four perspectives

\begin{tabular}{|c|c|c|c|c|c|}
\hline Overall & European Union State & Political & Economical & Sociological & Technological \\
\hline A & Netherlands & A & A & A & A \\
\hline A & Denmark & A & A & A & A \\
\hline A & Sweden & A & A & A & A \\
\hline A & Luxembourg & B & A & A & A \\
\hline A & Austria & A & A & A & A \\
\hline A & Finland & A & B & A & A \\
\hline A & Germany & A & A & B & A \\
\hline A & Belgium & A & A & A & A \\
\hline A & United Kingdom & B & A & B & A \\
\hline A & Ireland & A & A & B & B \\
\hline B & Spain & A & $\mathrm{C}$ & A & B \\
\hline B & Slovenia & B & B & B & B \\
\hline B & Malta & $\mathrm{C}$ & A & B & B \\
\hline B & France & B & B & B & B \\
\hline B & Czech Republic & B & B & B & B \\
\hline B & Portugal & A & $\mathrm{C}$ & $\mathrm{B}$ & B \\
\hline B & Italy & $\mathrm{C}$ & B & A & B \\
\hline B & Estonia & B & B & $\mathrm{C}$ & A \\
\hline B & Cyprus & $\mathrm{C}$ & B & B & B \\
\hline B & Poland & B & $\mathrm{C}$ & $\mathrm{B}$ & B \\
\hline $\mathrm{C}$ & Greece & $\mathrm{C}$ & $\mathrm{C}$ & A & $\mathrm{C}$ \\
\hline $\mathrm{C}$ & Lithuania & B & $\mathrm{C}$ & $\mathrm{C}$ & B \\
\hline $\mathrm{C}$ & Hungary & B & B & $\mathrm{C}$ & $\mathrm{C}$ \\
\hline $\mathrm{C}$ & Slovak Republic & $\mathrm{C}$ & B & $\mathrm{C}$ & $\mathrm{C}$ \\
\hline $\mathrm{C}$ & Latvia & $\mathrm{C}$ & $\mathrm{C}$ & $\mathrm{C}$ & B \\
\hline $\mathrm{C}$ & Croatia & $\mathrm{C}$ & $\mathrm{C}$ & $\mathrm{C}$ & $\mathrm{C}$ \\
\hline $\mathrm{C}$ & Bulgaria & $\mathrm{C}$ & $\mathrm{C}$ & $\mathrm{C}$ & $\mathrm{C}$ \\
\hline $\mathrm{C}$ & Romania & $\mathrm{C}$ & $\mathrm{C}$ & $\mathrm{C}$ & $\mathrm{C}$ \\
\hline
\end{tabular}




\subsection{Geographical analysis}

Geographical analysis shows that the countries graded as category A are located mostly in northern Europe, the exception being Austria, which is in central Europe. The countries graded B are located in western, central and southern Europe, except for Estonia. The countries graded $\mathrm{C}$ are located in eastern and southern Europe.

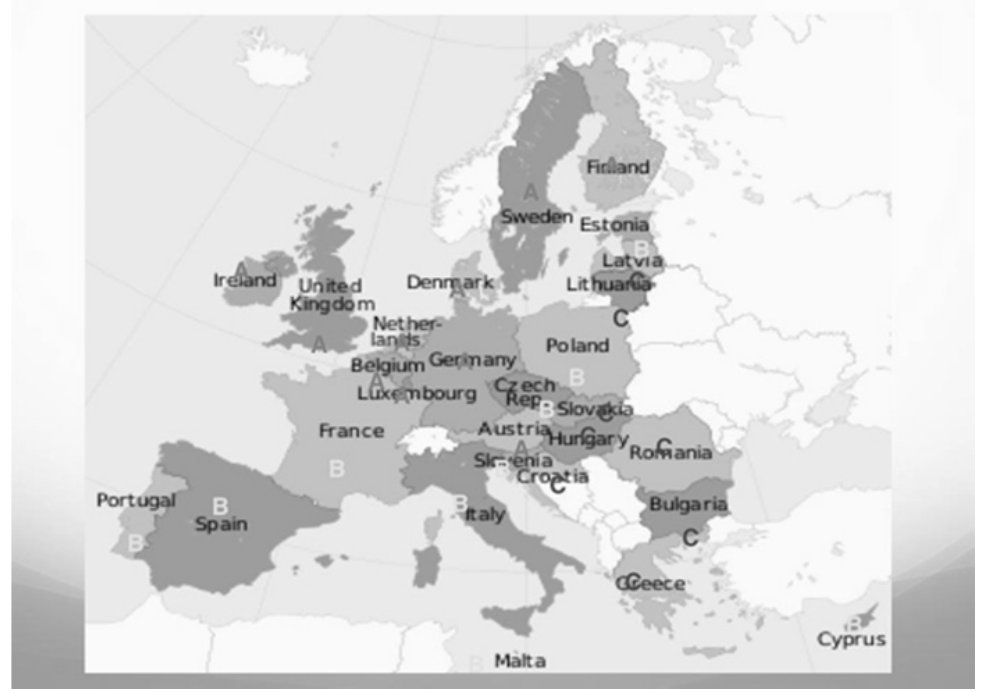

Figure 2: Geographical analysis of the overall classification of the 28 UE countries

\section{Applying the dominance-based rough set approach to determining strategic developmental objectives for Poland}

This approach consists of searching for a reduced set of attributes that ensures the same quality of object classification as does the original set of attributes. In rough set theory, the decision problem is represented by a decision table whose rows represent the objects while the columns represent the attributes (Table 3).

Table 3: Decision table

\begin{tabular}{|c|c|c|c|c|}
\hline & $\mathbf{X}_{1}$ & $\ldots$ & $\mathbf{X}_{\mathrm{m}}$ & $\mathbf{D}$ \\
\hline $\mathrm{a}_{1}$ & $e\left[\left(a_{1}\right), 1\right]$ & $\ldots$ & $e\left[\left(a_{1}\right), m\right]$ & $e\left(a_{1}\right)=\{\mathrm{A}, \mathrm{B}$, or $\mathrm{C}\}$ \\
\hline $\mathrm{a}_{2}$ & $e\left[\left(a_{2}\right), 1\right]$ & $\ldots$ & $e\left[\left(a_{2}\right), m\right]$ & $e\left(a_{2}\right)=\{\mathrm{A}, \mathrm{B}$, or $\mathrm{C}\}$ \\
\hline$\ldots$ & $\ldots$ & $\ldots$ & $\ldots$ & $\ldots$ \\
\hline $\mathrm{a}_{\mathrm{n}}$ & $e\left[\left(a_{n}\right), 1\right]$ & $\ldots$ & $e\left[\left(a_{n}\right), m\right]$ & $e\left(a_{n}\right)=\{\mathrm{A}, \mathrm{B}$, or $\mathrm{C}\}$ \\
\hline
\end{tabular}


In our approach, the objects are the 28 countries; two types of attributes are used: conditional and decisional. The conditional attributes represent the values of the indicators, and we have only one decisional attribute, which is represented by the grade category, A, B or C in the overall classification or with respect to a given perspective.

\subsection{The decision rules}

To obtain the decision rules, we used 4eMka2 software, which was developed by the Intelligent Decision Support Systems Laboratory (IDSS) at the Computing Science Institute of the Poznan University of Technology (Greco et al., 1999). Rules for the four perspectives combined are presented below in Table 4. Since we were interested in the most significant combination, we kept only rules with a minimal relative strength of $25 \%$ and those that were limited to three conditional criteria.

Table 4: Decision rules for all perspectives combined

\begin{tabular}{|c|c|c|}
\hline$\#$ & Decision rules & Condition $\mathbf{1}$ \\
\hline 1 & Decision $\geq \mathrm{A}$ & Corruption Perception Index $\geq 73$ \\
\hline 2 & Decision $\geq \mathrm{B}$ & Mobile cellular subscriptions $\geq 146.21$ \\
\hline 3 & Decision $\geq \mathrm{B}$ & GNI per capita $\geq \$ 19,880$ US \\
\hline
\end{tabular}

Rule 1 indicates that in order to earn a category A score, the Corruption Perception Index (CPI) must be at least 73. Rules 2 and 3 indicate that to be scored as category B, the number of mobile phones subscriptions per 100 habitants needs to be greater than 146.21 or GNI per capita at least $\$ 19,880$.

Poland is thus potentially upgradable from B to A based on Rule 1, by improving its $\mathrm{CPI}$ to at least 73 . We also know from the sorting problem that to move to category $\mathrm{A}$, at least two perspectives must be scored $\mathrm{A}$, and no $\mathrm{C}$ score is allowed. Table 5 describes the rules for each of the four PEST perspectives.

In the economic perspective, Poland received a $\mathrm{C}$ score. To upgrade to $\mathrm{B}$, gross national income and exports of goods and services should be improved at the same time (Rule 13).

In the political perspective, Poland could improve the Perception of Corruption Index, which should be at least 90, or improve the competitiveness index, since the Ease of Doing Business condition is met. Cutting military spending is incompatible with Polish government's strategy. 
Table 5: Decision rules for each PEST perspective

\begin{tabular}{|c|c|c|c|c|}
\hline$\#$ & Decision Rule & Condition 1 & Condition 2 & Condition 3 \\
\hline & $\begin{array}{c}\text { Political } \\
\text { Perspective }\end{array}$ & & & \\
\hline 4 & Decision $\geq \mathrm{A}$ & Corruption index $\geq 90$ & & \\
\hline 5 & Decision $\geq \mathrm{A}$ & $\begin{array}{c}\text { Competitiveness index } \geq \\
5.65 \\
\end{array}$ & $\begin{array}{c}\text { Ease of doing business } \leq \\
28 \\
\end{array}$ & \\
\hline 6 & Decision $\geq \mathrm{A}$ & $\begin{array}{c}\text { Military expenditure } \leq \\
1.47 \\
\end{array}$ & $\begin{array}{c}\text { Women in government } \geq \\
30.6 \%\end{array}$ & \\
\hline \multirow[t]{2}{*}{7} & Decision $\geq \mathrm{B}$ & $\begin{array}{c}\text { Military expenditure } \leq \\
1.47\end{array}$ & $\begin{array}{c}\text { Ease of doing business } \leq \\
52\end{array}$ & \\
\hline & $\begin{array}{c}\text { Economic } \\
\text { Perspective } \\
\end{array}$ & & & \\
\hline 10 & Decision $\geq \mathrm{A}$ & Unemployment $\leq 3.8 \%$ & GNI per capita $\geq \$ 43,850$ & \\
\hline 11 & Decision $\geq \mathrm{B}$ & $\begin{array}{l}\text { Export of goods and } \\
\text { services } \geq 121.58 \%\end{array}$ & & \\
\hline 12 & Decision $\geq \mathrm{B}$ & GNI per capita $\geq \$ 56,990$ & & \\
\hline \multirow[t]{2}{*}{13} & Decision $\geq \mathrm{B}$ & $\begin{array}{c}\text { Export of goods and } \\
\text { services } \geq 82.87 \%\end{array}$ & GNI per capita $\geq \$ 41,820$ & \\
\hline & $\begin{array}{l}\text { Sociological } \\
\text { Perspective }\end{array}$ & & & \\
\hline 14 & Decision $\geq \mathrm{A}$ & Years of schooling $\geq 19$ & $\begin{array}{c}\text { Adolescent fertility } \leq 6.38 \\
\text { per } 1000\end{array}$ & \\
\hline 15 & Decision $\geq \mathrm{B}$ & Homicide $\leq 1.25$ & & \\
\hline 16 & Decision $\geq \mathrm{B}$ & Years of schooling $\geq 19$ & & \\
\hline \multirow[t]{2}{*}{17} & Decision $\geq \mathrm{B}$ & Homicide $\leq 1.25$ & $\begin{array}{c}\text { Adolescent fertility } \leq 6.38 \\
\text { per } 1000 \\
\end{array}$ & $\begin{array}{c}\text { Urban population } \geq \\
59.28 \% \\
\end{array}$ \\
\hline & $\begin{array}{c}\text { Technological } \\
\text { Perspective } \\
\end{array}$ & & & \\
\hline 18 & Decision $\geq \mathrm{A}$ & Scientific articles $\geq 378.35$ & & \\
\hline 19 & Decision $\geq \mathrm{A}$ & $\begin{array}{c}\text { Mobile phones } \geq 148.68 \\
\text { per } 100 \text { persons }\end{array}$ & & \\
\hline 20 & Decision $\geq \mathrm{B}$ & $\begin{array}{c}\text { Mobile Phones } \geq 129.95 \\
\text { per } 100 \text { persons }\end{array}$ & & \\
\hline 21 & Decision $\geq \mathrm{B}$ & $\begin{array}{c}\text { Mobile phones } \geq 111 \text { per } \\
100 \text { persons }\end{array}$ & $\begin{array}{c}\text { Fixed Internet } \geq 38.01 \\
\text { subscriptions per } 100\end{array}$ & \\
\hline
\end{tabular}

In the sociological perspective, Poland could upgrade to category A by increasing years of schooling and reducing adolescent fertility. From the technological perspective, Poland could increase spending on research, which would increase the number of scientific papers, or it could increase the number of mobile phones. The strategic objective should be formulated to introduce the quantitative notion of increasing the value of the indicator to satisfy the condition based on the decision rule in relation to the current level. 


\section{$4 \quad$ Strategic decision-making}

In this section, we show the practical application and usefulness of the decision rules for achieving sustainable political, economic, sociological and technological development in Poland. The decision rules set targets for the improvements specified in the strategic objectives. These targets are based on the statistical data used to extract the decisional rules.

\subsection{Strategic objectives and measurements of performance}

Table 6 describes various strategic objectives that would be appropriate for Poland. The decision rules set the targets that must be reached for each objective. It is possible that some decision rule conditions are already satisfied, in which case the objective would be to maintain them at their current values. All other values become objectives that would elevate the status of Poland from $\mathrm{B}$ to $\mathrm{A}$. It is important to note that Poland is in category $\mathrm{C}$ economically and that at least two objectives listed in this perspective would have to be achieved.

Table 6: Strategic objectives and targets for Poland

\begin{tabular}{|c|c|c|c|}
\hline All perspectives & Strategic objective 1 & Strategic objective 2 & Strategic objective 3 \\
\hline Decision rule \#1 & $\begin{array}{l}\text { Improve the corruption } \\
\text { perception index by } 11 \\
\text { points }\end{array}$ & & \\
\hline Political perspective & Strategic objective 1 & Strategic objective 2 & Strategic objective 3 \\
\hline Decision rule \#2 & $\begin{array}{c}\text { Improve the corruption } \\
\text { perception index by } 28 \\
\text { points }\end{array}$ & & \\
\hline Decision rule \#3 & $\begin{array}{c}\text { Improve the } \\
\text { competitiveness index by } \\
\text { at least } 1.06 \text { points }\end{array}$ & \begin{tabular}{|c} 
Maintain the ease of doing \\
business below 28 \\
(currently 27)
\end{tabular} & \\
\hline Decision rule \#4 & $\begin{array}{c}\text { Reduce military expenditure } \\
\text { by } 0.46 \text { points }\end{array}$ & $\begin{array}{l}\text { Improve the proportion of } \\
\text { seats held by women in } \\
\text { national parliaments by } \\
2.6 \% \text {. }\end{array}$ & \\
\hline Economic perspective & Strategic objective 1 & Strategic objective 2 & Strategic objective 3 \\
\hline Decision rule \#5 & $\begin{array}{c}\text { Reduce unemployment by } \\
1.3 \%\end{array}$ & $\begin{array}{c}\text { Improve the gross national } \\
\text { income by } \$ 31,160 \text { per } \\
\text { capita }\end{array}$ & \\
\hline Decision rule \#6 & $\begin{array}{c}\text { Improve exports of goods } \\
\text { and services by } 69.32 \% \text { of } \\
\text { GNP }\end{array}$ & & \\
\hline
\end{tabular}


Table 6 cont.

\begin{tabular}{|c|c|c|c|}
\hline Economic perspective & Strategic objective 1 & Strategic objective 2 & Strategic objective 3 \\
\hline Decision rule \#7 & $\begin{array}{c}\text { Improve the gross national } \\
\text { income by } \$ 44,300 \text { per } \\
\text { capita }\end{array}$ & & \\
\hline Decision rule \#8 & $\begin{array}{c}\text { Improve exports of goods } \\
\text { and services by } 30.61 \% \text { of } \\
\text { GNP }\end{array}$ & $\begin{array}{c}\text { Improve the gross national } \\
\text { income by } \$ 29,130 \text { per } \\
\text { capita }\end{array}$ & \\
\hline $\begin{array}{l}\text { Sociological } \\
\text { perspective }\end{array}$ & Strategic objective 1 & Strategic objective 2 & Strategic objective 3 \\
\hline Decision rule \#9 & $\begin{array}{c}\text { Increase schooling by } 3 \\
\text { years }\end{array}$ & $\begin{array}{c}\text { Reduce adolescent fertility } \\
\text { by } 6.65 \text { per } 1000\end{array}$ & \\
\hline $\begin{array}{l}\text { Technological } \\
\text { perspective }\end{array}$ & Strategic objective 1 & Strategic objective 2 & Strategic objective 3 \\
\hline Decision rule \#10 & $\begin{array}{c}\text { Increase by } 220.97 \text { the } \\
\text { number of scientific articles } \\
\text { published per } 1000000 \\
\text { persons }\end{array}$ & & \\
\hline Decision rule \#11 & $\begin{array}{l}\text { Increase mobile cellular } \\
\text { subscriptions by } 2.47 \text { per } \\
100 \text { persons }\end{array}$ & & \\
\hline
\end{tabular}

1) In the overall classification, Poland could move from category B to A by increasing its Corruption Perception Indicator by at least 11 points.

2) For economic classification purposes, rules 6 and 7 are extremely demanding, while rule 8 would be easier to satisfy. Poland could upgrade from C to B by increasing GNI per capita by $\$ 29,130$ and increasing exportations of goods and services by $30.6 \%$ of GNP.

3) From the political perspective, upgrading from B to A status by rule 3 would be easier for Poland provided that the ease of doing business index were maintained at its current level while the competitiveness index increased by at least 1.06 points.

4) From the sociological perspective, it is clear that Poland needs to increase schooling by at least three years and reduce its adolescent fertility index by at least 6.65 per 1000 to move from B to A status.

5) From the technological perspective, Poland could upgrade from $B$ to A status most easily by focusing on rule 11 , since there would be relatively few obstacles to increasing the number of mobile phone subscriptions by 2.47 or more per 100 persons. 


\section{Conclusions}

In this study, it was shown that DRSA can be used to obtain a classification of European Union countries for the purpose of designing strategic goals intended to improve their political, economic, sociological and technological status. The decision rules showed the boundary values defining each category and the criterion values which were used to assign Poland to its category.

Overall, the Polish government appears to be effective. It is fighting corruption and the CBA agencies or others doing similar work have met with success in reducing the VAT gap.

The most direct way for Poland to improve its status would be to increase its GDP and per capita GNI. This would be achievable only in the long term. According to the data available, this would earn Poland an A classification, in line with the leading countries of the European Union. Per capita GNI would have to reach at least $\$ 43,850$ and unemployment would have to be $3.8 \%$ or lower. A more realistic economic strategic objective that could be pursued in a shorter term would be to increase its exportation of goods and services.

Strategic objectives in the political realm are very close to being attained thanks to laws and regulations implemented to improve the ease of doing business index and the competitiveness index.

Our analysis indicates that the Polish government could further improve its political status by reducing its military expenditure index. However, in reality, the Polish government cannot do this because of its NATO obligations, which require raising military spending to $2.5 \%$ of GDP to ensure the security of the eastern front.

Certain sociological improvements would upgrade the overall classification of Poland from B to A status, particularly in years of schooling and life expectancy. Efforts could be deployed also to reduce the adolescent fertility rate, even though the birth rate needs to be increased overall just to maintain the population.

From the technological perspective, the objective of increasing the number of cell phones is very realistic even though considerable investment would be required to increase network capacity.

\section{References}

Emam O., Farhan M., Abohany A. (2017), Faults Repairing Analysis Using Rough Sets after Implementation of Labor Force Redistribution Algorithm: A Case Study in Telecom Egypt, Information Sciences Letter, 6(3), 39-48.

Field A. (2005), Discovering Statistics Using SPSS, 2nd Edition, SAGE Publications, New Delhi. 
Greco S., Matarazzo B., Slowinski R. (1999), The Use of Rough Sets and Fuzzy Sets in MCDM, [in:] T. Gal, T. Hanne, T. Stewart (eds.), Advances in Multiple Criteria Decision Making, Kluwer Academic Publishers, Dordrecht, Boston, 14.1-14.59.

Greco S., Matarazzo B., Slowinski R. (2001), Rough Sets Theory for MultiCriteria Decision Analysis, European Journal of Operational Research, 129, 1-47.

Ho H.-Ch., Fann W.J.-D., Chiang H.-J., Nguyen P.-T., Pham D.-H., Nguyen P.-H., Nagai M. (2016), Application of Rough Set, GSM and MSM to Analyze Learning Outcome - An Example of Introduction to Education, Journal of Intelligent Learning Systems and Applications, 8, 23-38.

International Institute for Strategic Studies, IISS, viewed 4 January 2018, https://www.iiss.org

Marin J.-C., Zaras K., Boudreau-Trudel B. (2014), Use of the Dominance-Based Rough Set Approach as a Decision Aid Tool for the Selection of Development Projects in Northern Quebec, Modern Economy, 5, 723-741.

Pawlak Z. (1982), Rough Set, International Journal of Parallel Programming, 11, 341-356.

Pawlak Z. (1991), Rough Sets: Theoretical Aspects of Reasoning about Data, Kluwer Academic Publishing, Dordrecht, http://dx.doi.org/10.1007/978-94-011-3534-4

Pawlak Z. (2002), Rough Set Theory and Its Applications, Journal of Telecommunications and Information Theory, 3, 7-10.

Pawlak Z., Slowinski R. (1994), Rough Set Approach to Multi-Attribute Decision Analysis, European Journal of Operational Research, 72, 443-459, http://dx.doi.org/10.1016/03772217(94)90415-4

Prema S., Umamaheswari P. (2016), Multitude Classifier Using Rough Set Jelinek-Mercer Naïve Bayes for Disease Diagnosis, Circuits and Systems, 7, 701-708.

Renaud J., Thibault J., Lanouette R., Kiss L.N., Zaras K., Fonteix C. (2007), Comparison of Two Multi-Criteria Methods: Net Flow and Rough Set Methods for Aid to Decision Making in a High Yield Pulping Process, European Journal of Operational Research, 177(3), 1418-1432.

Songbian Z. (2016), Business Intelligence from Customer Review Management Using Rough Set Model, International Journal of Advanced Research, 4, 816-824.

United Nations 2018, UNData, viewed 4 January 2018, http://data.un.org/Explorer.aspx?d= UNODC

World Bank 2018, Indicators, viewed 4 January 2018. https://data.worldbank.org/indicator.

Zaras K. (2004), Rough Approximation of a Preference Relation by a Multi-attribute Stochastic Dominance for Deterministic, Stochastic and Fuzzy Evaluation Problems, European Journal of Operational Research, 159, 196-206.

Zaras K., Marin J.-C., Boudreau-Trudel B. (2012), Dominance Rough Set Approach as a Decision-Making Method for the Selection of Sustainable Development Projects, American Journal of Operational Research, 2, 506. 